\title{
Sea Water Intrusion in a Coastal Aquifer: A Case Study for the Area Between Seeb and Suwaiq, Sultanate of Oman
}

\author{
Ahmed Al Barwani* and Tariq Helmi \\ Ministry of Regional Municipalities, Environment and Water Resources, \\ P.O. Box 2575 Ruwi, P C 112 Ruwi, Sultanate of Oman

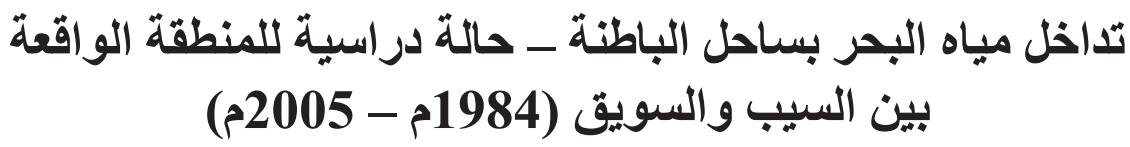 \\ أحمد بن سعيد البرواني وطارق حلمي أبو العطا
}

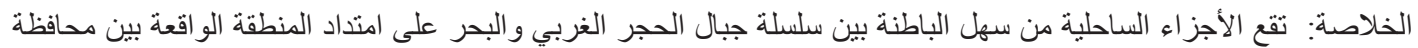

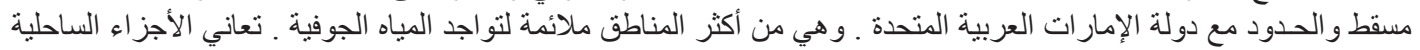

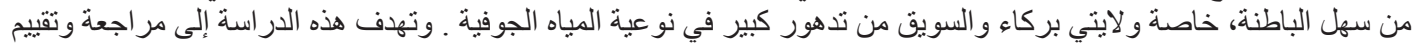

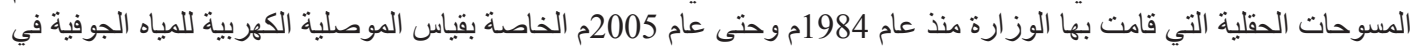

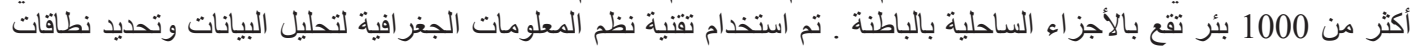

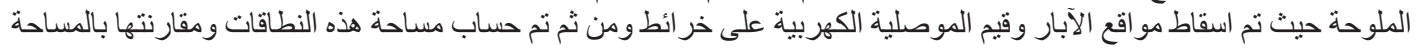

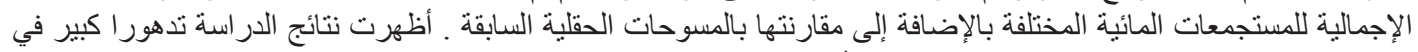

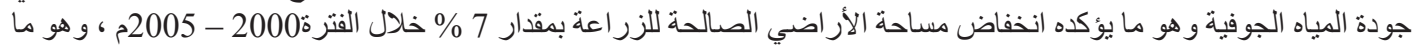

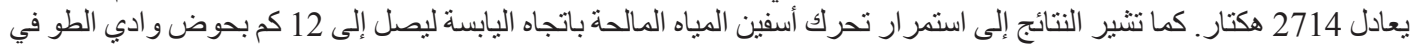

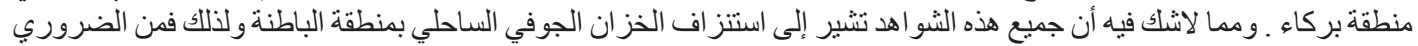

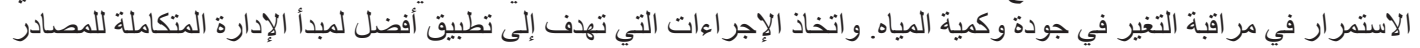

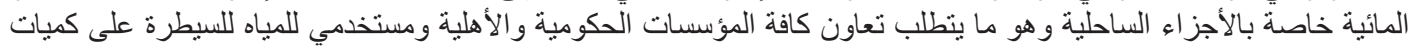

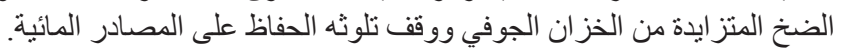

ABSTRACT: The Batinah Coastal plain, located between the Hajar mountains and the sea, from Muscat to the UAE border, is a favorable region for groundwater occurrence in Oman and the main source of fresh water in this coastal area. The coastal parts of the Batinah plain, particularly Barka and Suwaiq, have suffered from groundwater deterioration over the past 20 years. This paper reviews the monitoring activities of groundwater electrical conductivity in the Batinah coastal plain between Seeb and Suwaiq over the period 1984 to 2005, an area of approximately $394 \mathrm{~km}^{2}$. GIS and Auto-Cad techniques were applied to illustrate different salinity zones as the wells coordinates and their field EC were digitized on maps with contours. Zones of salinity ranges are identified and their areas were computed and compared to the total catchment area of each wadi. All samples were collected from the same upper gravel layer, ranging in depth 20-100 meters. There has been a substantial deterioration in water quality as indicated by a $7 \%$ reduction in areas of water suitable for agriculture use $(2.000-6.000 \mu \mathrm{S} / \mathrm{cm})$, reflecting a loss of 2,714 hectares of irrigated land. Also, a saline interface is reported $12 \mathrm{~km}$ inland at Wadi al Taww, Barka area, an indication of aquifer over-exploitation. It is therefore critical that monitoring of water quality and quantity is continued. It is recommended to improve implementation of the standard water resources management solutions to coastal aquifer saline contamination. Cooperation of different organizations and water users is essential to conserve these precious water resources.

Keywords: Groundwater, water quality, water resources management.

$\overline{\text { * Corresponding author. E-mail: asbarwan@yahoo.com }}$ 


\section{Introduction}

The Batinah coastal plain extends $270 \mathrm{~km}$ along the Gulf of Oman from Muscat to the U.A.E. border, north of Shinas. The area is of critical importance to the agricultural economy of the Sultanate; $50 \%$ of the total agriculture area is located here. Population growth and rapid industrial and agricultural development in this area, and hence the conjugate increase in different human activities, have imposed an increasing demand for fresh water. This increased demand has been met by the extensive pumping of fresh groundwater water, causing a subsequent lowering of the water table and upsetting the natural balance between the fresh and saline water body. The result is salt water intrusion.

Being heavier than fresh water, salt water occurs as a wedge beneath the fresh water; the two mix in a transition zone or zone of diffusion, in which the water becomes progressively more saline downwards and towards the sea. The existence of a transition zone indicates that there is a significant circulation of seawater into and out of the aquifer. A continuous movement of fresh water through the zone produces a natural barrier that prevents saline water from moving further inland. Under limited pumping of water from wells, the through flow of fresh groundwater to the sea is maintained by recharge in the upper parts of the aquifers and the transition zone holds a fairly constant position. When excessive pumping alters this equilibrium, particularly near the coast, groundwater levels fall, with the flow of fresh water being reduced and the transition zone moving inland and upwards. As a result, water pumped from wells near the coast becomes progressively more saline.

Groundwater abstraction for irrigation in the South Batinah areas is extremely high compared to the North Batinah areas. Therefore, groundwater recharge and abstraction are important factors controlling saline intrusion in the South Batinah. Preventing the saline water intrusion along the Batinah coast depends on continuous recharge events from rainfall and wadi flows and also on controlling the over pumping from wells.

This study focuses on monitoring of the groundwater salinity in the area between Seeb and Suwaiq to detect the lateral variation in salinity of the shallow upper gravel layer of the Batinah aquifer.

\section{Hydrogeology of Al Batinah}

The hydrogeology of the Batinah is an important factor in the occurrence of groundwater. Through millions of years, the plain has been formed by the effect of natural processes such as rainfall and weathering.
Rainfall on the mountain area has spread sediments to build up the plain and complex patterns of gravel and clay have been formed in the braided wadi channels (Stanger, 1984).

The Batinah area can be divided into two main parts, differentiated by rock type and geological setting, namely: the mountains, composed of hard rocks mainly igneous rocks overlain by ophiolite sediments with some sandstones and conglomerates underlain by several thrust sheets of pelagic sediments and tertiary limestone; and the lowland and coastal plain, consisting mainly of coarse gravels and boulders with occasional cemented beds. The latter is the main aquifer with a total depth of more than $300 \mathrm{~m}$ in the Sohar-Saham area and more than $600 \mathrm{~m}$ in the Seeb-Barka area in the South Batinah. The alluvial deposits generally become finer toward the coast and the interfluve area between the systems of braided channels.

These deposits form a single deep groundwater basin along the Batinah containing relatively fresher groundwater inland where saline intrusion exists near the coast. They are hydrogeologically divided into upper gravels, clayey gravels and cemented gravels. Low lands or Piedmont Zone comprise the upper gravel unit and constitute the main productive zone as the thickness increase towards the sea. Although grain size, degree of sorting, and cementation with calcium carbonate affect this unit hydraulically, its storage and transmissivity are generally good, with average transmissivity values of $550 \mathrm{~m}^{2} /$ day in the BarkaSuwaiq area (South Batinah). The transmissivity in the Sohar-Saham area (North Batinah) is 3000 $\mathrm{m}^{2}$ /day or even larger $\left(6500 \mathrm{~m}^{2} /\right.$ day $)$, due to either higher proportion of coarser materials caused by the narrowness of the coastal plain or a greater aquifer thickness. Underlying the upper gravels are the clayey gravels, marked by the appearance of brown and red marly gravels and clayey sands associated with decreased well yields and average transmissivity about $223 \mathrm{~m}^{2} /$ day. Located at the bottom of the clayey gravel sequence are the cemented gravels with the smallest specific capacities and biggest drawdowns, thus making them markedly poorer aquifers (MWR, 1995).

Groundwater quality along the Batinah is extremely varied. In the mountains near the recharge source, water quality is good, with TDS of less than $1500 \mathrm{mg} / \mathrm{l}$. In the plain and lowland area, water 
quality decreases as groundwater dissolves many salts (calcium carbonate) on its way to the sea, with higher TDS values in the range 1500 to $6500 \mathrm{mg} / \mathrm{l}$ associated with the larger settlements. In the coastal zone the freshwater aquifer is underlain by a saltwater wedge.

The prevailing rainfall pattern in the area is characterized as having the wettest months from February to April, which account an average for $40 \%$ of the total annual rainfall. A second but less pronounced relatively wet period is July and August, accounting for another 23\%. Mean Annual Rainfall (MAR) varies from about $55 \mathrm{~mm}$ at the coast to about $310 \mathrm{~mm}$ in the mountains. During the period covered by this study (1984-2005), three significant dry periods and four significant wet periods can be identified (MWR, 2000): dry periods are 1979-81, 1984-86, 1991-94. The five year moving mean plots for all the available long-term stations (22-years) in the area indicates that there is no particular long-term trend and there is no evidence of any statistically significant trend to suggest any climatic change is occurring in the area.

\section{Materials and Methods}

Monitoring salt-water intrusion beneath the Batinah coastal plain is carried out at hundreds of hand dug coastal wells. The Public Authority for Water Resources undertook three extensive surveys, covering the entire Batinah coast over the period 1982 to 1984 . The surveys were repeated during 1985, 1986 and 1988 for some parts of the Batinah coast, and then in 1989, 1991, 1993, 1995, 1997, 2000 and 2005. The field surveys included measurements of 716 wells ( $90 \%$ of them being productive) located along the study area $\left(394 \mathrm{~km}^{2}\right)$ on both sides of the Batinah Coast highway: 221 wells located in the Seeb area, 186 wells at Wadi Al Taww, 113 wells at Wadi Al Maawil, 99 wells at Wadi Bani Kharous, and 97 wells at Wadi Al Fara'a.

Water samples were collected from all productive wells and non-pumped wells were pumped using an MP1 pump with 2 inch diameter. To obtain a representative groundwater sample, it was necessary to purge the bore to remove the stagnant water from the bore water column. This was achieved by removing about three times the volume of water contained in the borehole before a sample was collected. The well depths ranged from 20 to 100 meters, tapping only the same upper gravel layer of the Batinah aquifer. The well locations (coordinates) and their field EC were digitized on maps where contours were produced using Auto-Cad techniques. Zones of salinity range were colored, their areas computed and compared to the total catchment area of each wadi, and the results plotted on the maps.

These surveys were designed to provide an overall picture of coastal salinity conditions and to demonstrate that a serious saline intrusion problem existed.

\section{Results and Discussion}

Present conditions indicate that fresh water discharge to the sea along the Batinah coast is largely intercepted by pumping in the coastal zone. The salt-water wedge is located several kilometers inland in some places and could pose a serious threat to existing municipal well fields. The top of the interface is approximately delineated by the red colored zones with EC $>16000$ mmhos/cm shown on Figures 1, 2 and 3.

Table 1 shows a severe water abstraction from the aquifer compared to the water available, particularly in the Barka area (Wadi Al Taww, Wadi Al Ma'awil) and the Suwaiq area (Wadi Al Fara, Wadi Bani Kharus). The Water Resources Master Plan (MWR, 2000), reported that total deficit amounts to $92.8 \mathrm{Mm}^{3}$ which is covered by storage depletion $\left(47 \mathrm{Mm}^{3}\right)$ and sea water intrusion $\left(45.8 \mathrm{Mm}^{3}\right)$. It should be also noted that both the storage depletion and saline intrusion flow components are not in steady state and may increase or decrease as the aerial extent of the depletion zone and the hydraulic head within that zone vary in response to changes in the groundwater abstraction pattern.

\section{The 2005 Salinity Survey Results}

The total study area covered $394 \mathrm{~km}^{2}$ and 716 wells, with an average spacing of $0.6 \mathrm{~km}^{2}$ per well. This study compares the 2005 survey with all the available ones since 1983. This comparison illustrates and emphasizes the extensive and serious expansion of the saline water intrusion beneath the Batinah coast, particularly in the area between Seeb and Suwaiq. The following are the most important results of the project (Figs. 4-8):

- $47 \%$ of the total measured wells (537) had salinity above $6.000 \mu \mathrm{S} / \mathrm{cm}, 18 \%$ with a salinity over 16.000 $\mu \mathrm{S} / \mathrm{cm}$, with the highest salinity equal to $57.000 \mu \mathrm{S} / \mathrm{cm}$ at Wadi Taw.

- The southern Batinah areas showed progressive salinity increases during the last decade in spite of the exceptional rainfall during 1995-1997. Figure 4 shows 
Table 1. Water balances and areas of over-abstraction (all values in MCM).

\begin{tabular}{|c|c|c|c|c|c|c|}
\hline \multirow[b]{2}{*}{ Area } & \multirow{2}{*}{ Recharge } & \multirow{2}{*}{$\begin{array}{r}\text { Water } \\
\text { Available }\end{array}$} & \multicolumn{3}{|c|}{ Water Consumed } & \multirow{2}{*}{ Deficit } \\
\hline & & & Agriculture & $\begin{array}{r}\text { Dom/ } \\
\text { Ind/Mun }\end{array}$ & Total & \\
\hline Seeb & 52.9 & 53.2 & 45.82 & 9.39 & 55.2 & -2 \\
\hline Barka- Suwaiq & 71.7 & 83.3 & 173.68 & 0.38 & 174.1 & -90.8 \\
\hline Total & 124.6 & 136.5 & 219.50 & 9.77 & 229.3 & -92.8 \\
\hline
\end{tabular}

Source: Water Resources Master Plan (MRMEWR, 2000).

the increasing trend in salinity during 1993-2005 at three selected different catchments.

- There has been substantial deterioration in water quality, indicated by the $7 \%$ reduction in areas of water suitable for agricultural use $(2.000-6.000 \mu \mathrm{S} / \mathrm{cm})$, reflecting a loss of 2,714 hectares of irrigated land and indicated by the closure of 116 wells along the study area during the last five years.

In general, the variation in the degree of deterioration or improvement of the upper aquifer at the coastal area is a direct response to the rate of abstraction at each catchment, rainfall periods and to the enhancement of recharge dams located at the upstream part of each catchment. For example, near Seeb, Wadi Samail has markedly improved and the EC has decreased over large areas. Al Khod recharge dam is directly upstream of the area of greatest improvement. It is known that the dam has contributed many millions of cubic metres of fresh water to the aquifer. However, it is beyond the scope of this study to separate and quantify the change in salinity due to the effect of the dam from that caused by natural recharge via wadi flow and rainfall.

Seeb Area: Wadis Rusayl, Samail and Al Hayl, Al Maabila and Al Manumah

These catchments (Fig. 1) were highly salinized by the time of the survey in 1991. During the five years 1995-2000, the area with high salinity water $(>10,000$ $\mu \mathrm{S} / \mathrm{cm}$ ) that could not be used for economic cropping decreased by $53 \%$ at Wadi Rusayl (Fig. 5). and by $37 \%$ at Wadi Al Hayl. However, the area with potable water in Wadi Maabilah reduced gradually to zero in 2000, compared to $12 \%$ in 1995 and 5\% in 1997 (Fig. 6). In the five years, 2000-2005 there has been a general deterioration in water quality in Wadi Samail and a decrease in the area covered by potable water $(<2000 \mu \mathrm{S} / \mathrm{cm})$. Also at Wadi Manumah there has been a notable deterioration in water quality as the area covered by the potable water reached zero in 2005 , compared to $4 \%$ in 2000 .

\section{Barka Area : Wadis Al Taw and Al Maawil}

In both these catchments (Fig. 2), the area underlain by very saline water has increased gradually since 1991 . Compared to 2000 , the area covered by water not suitable for agriculture $(6,000 \mu \mathrm{S} / \mathrm{cm})$ has increased by 2000 hectares at both wadis (Fig. 7). In addition, the fresh water zone $(<2000 \mu \mathrm{S} / \mathrm{cm})$ in both wadis has decreased from $23 \mathrm{~km}^{2}$ in 1991 to zero in 2000 and 2005. In Wadi Maawil the area covered by high salinity water $(>16.000 \mu \mathrm{S} / \mathrm{cm})$ has increased from $17 \%$ in 2000 to $32 \%$ in 2005 . The continued inland movement of the saline intrusion is proceeding in connection with the steady decline in water levels below sea level. Even the exceptional rainfall during 1995-1997 was not enough to prevent the saline intrusion in this area. Low average rainfall and wadi flow during 1998-2004 allowed further water quality deterioration.

\section{Suwaiq Area: Wadis Bani Kharous and Al Fara}

In Wadi Bani Kharous, the water quality has deteriorated since 1991 (Fig. 3). Groundwater has become unsuitable for most crops at half of the wells in the area, as indicated by a steady increase in the area of very high saline water $(>16000 \mu \mathrm{S} / \mathrm{cm})$ since $1991(29 \%$ to $38 \%)$. Compared to 1997 , the area of potable drinking water $(<2000 \mu \mathrm{S} / \mathrm{cm})$ has decreased by $2 \%$ to reach zero in 2000 and 2005 (Fig. 8).

The same situation was recorded at Wadi Al Fara; there has been an increase in the area of high 


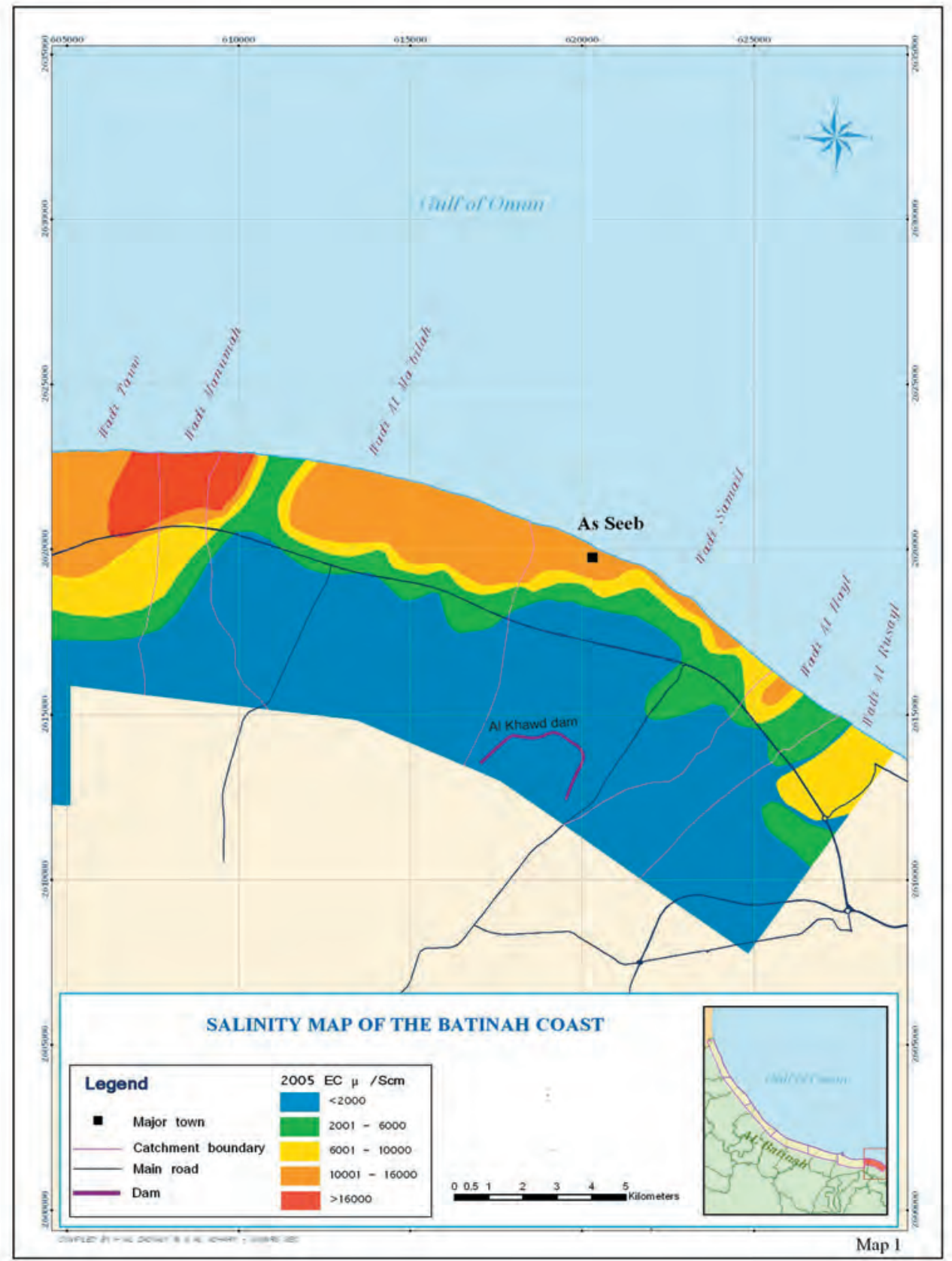

Figure 1. Groundwater salinity map for the Seeb area. 


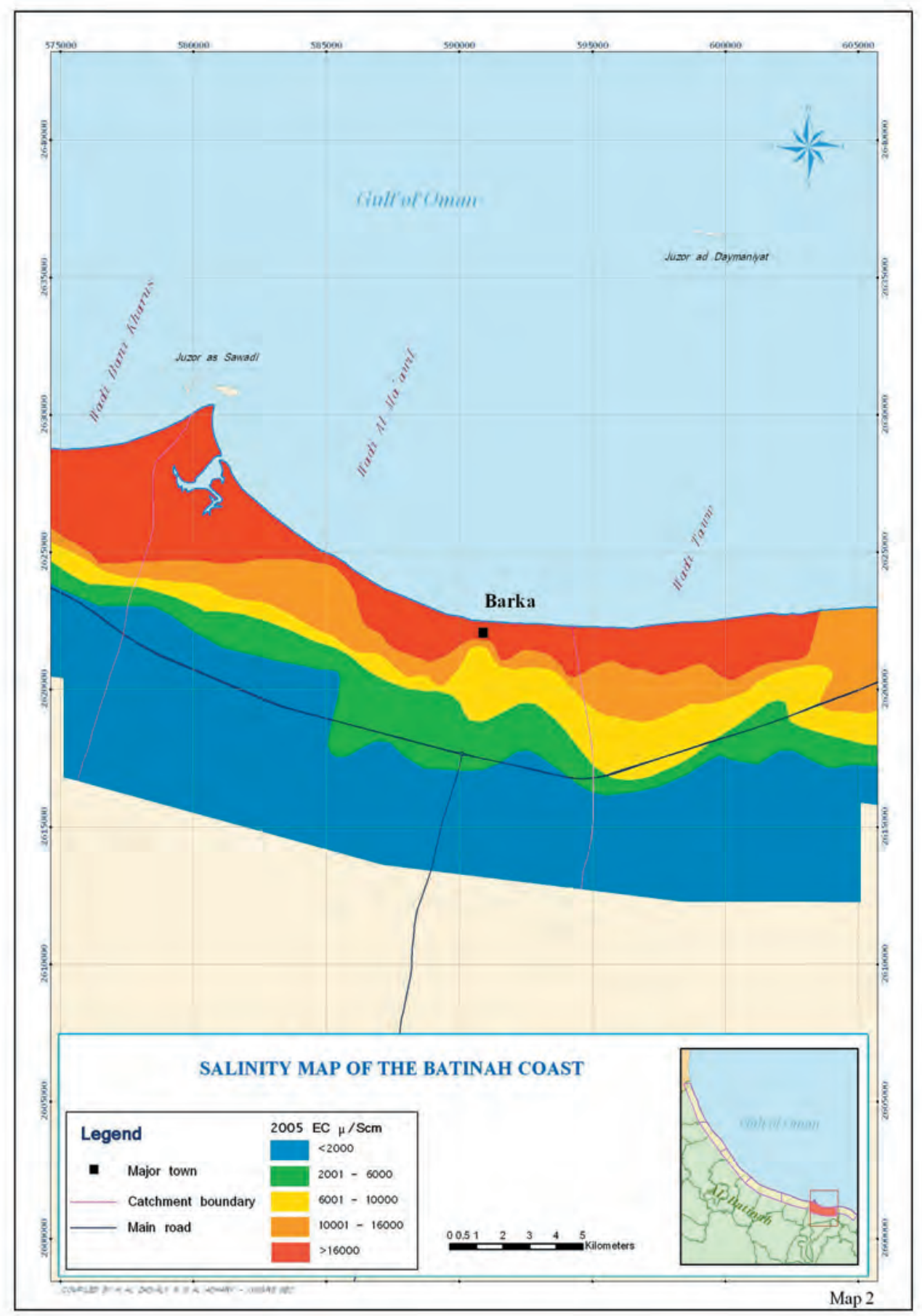

Figure 2. Groundwater salinity map for the Barka area. 


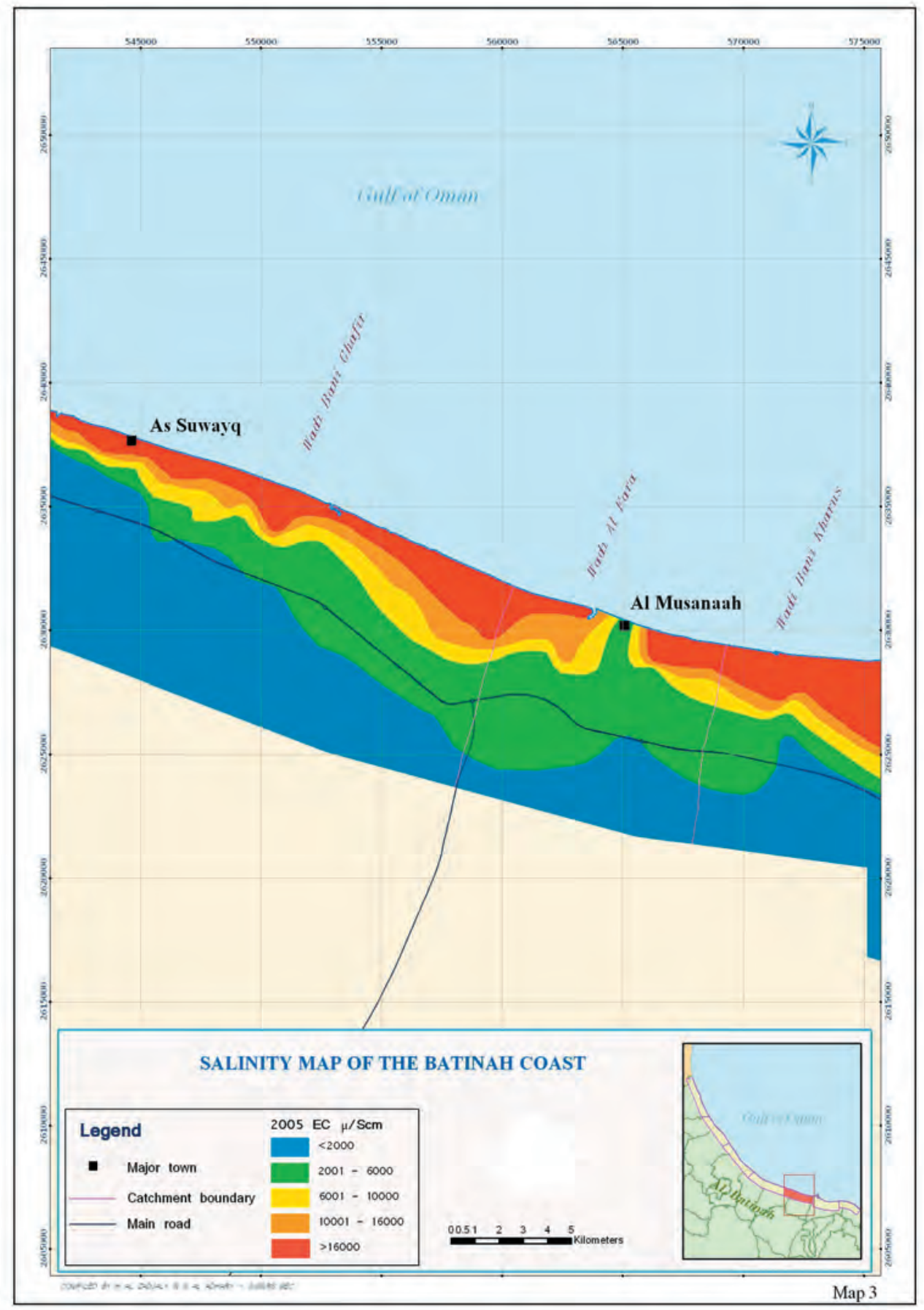

Figure 3. Groundwater salinity map for the Suwaq area. 


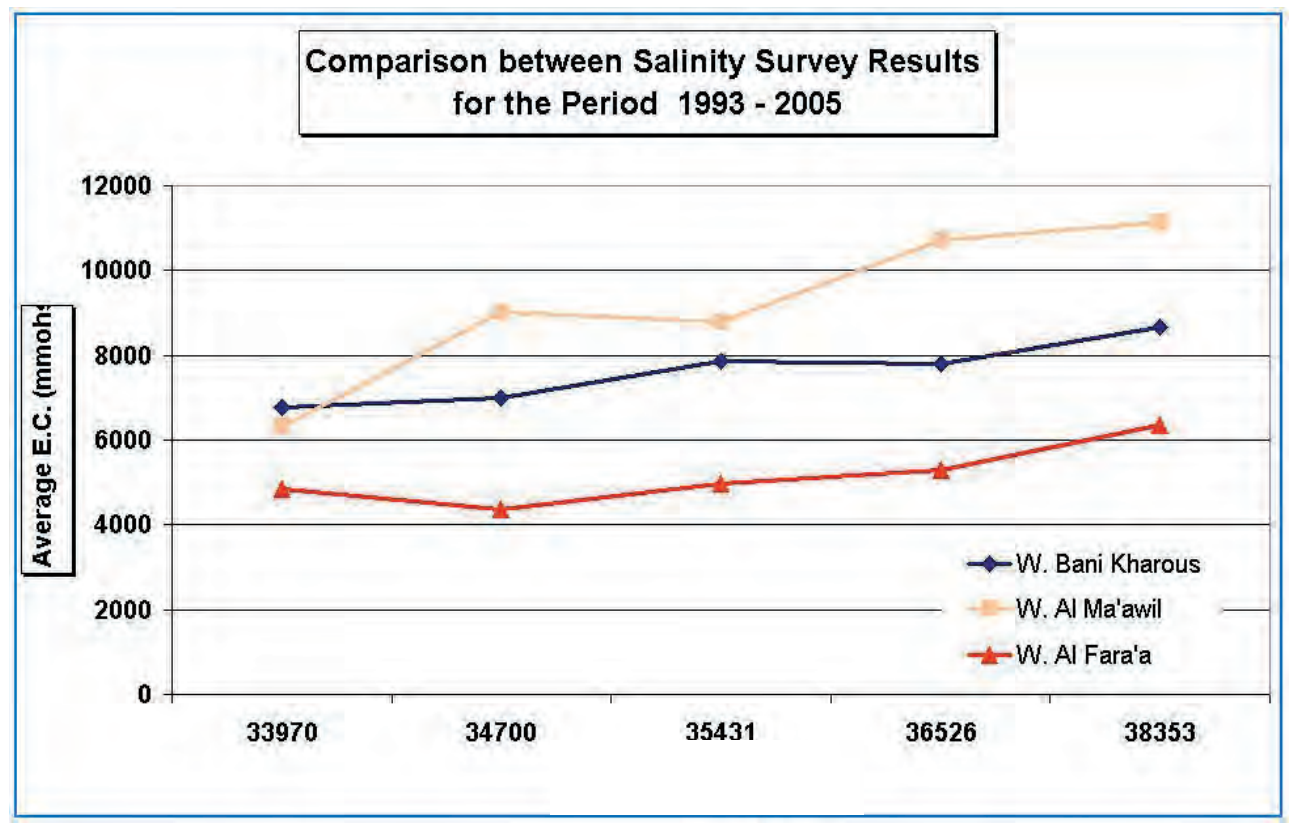

Figure 4. Increasing trend in salinity 1993-2005 at three different catchments.

saline water $(>10.000 \mu \mathrm{S} / \mathrm{cm})$ from $4 \%$ in 2000 to $8 \%$ in 2005. On the other hand, there has been a slight improvement in the area with potable water located in Wadi Fara. This could be a result of the recharge effect of Al Fara dam, situated upstream. In general there has been a notable water quality deterioration during the last ten years in the Suwaiq area.

\section{Rainfall}

The analysis of rainfall data in twenty nine rainfall stations, which goes back to 1990 in south Batinah and Muscat reveals that the annual average rainfall is $158 \mathrm{~mm}$ in South Batinah and $100 \mathrm{~mm}$ in Muscat. The analysis of the average rainfall at $\mathrm{Al}$ Khadrah rainfall station in South Batinah shows that water years, 1990, 1992, 1994, 1995, 1997, 1999 recorded above average annual rainfall (Fig. 9). The water year 1997 is considered a wet year for the Sultanate in general and for the Batinah specially: the total recorded cumulative rainfall was $608 \mathrm{~mm}$ in South Batinah. This is the highest on record since 1990 . Figure 10 represents the departure from mean annual rainfall at Muscat rainfall station for the last one hundred years. The figure shows that the area has been subjected to a severe dry period during the past seven years.

\section{Effects of rainfall on groundwater levels}

The water levels response to recharge events along the Batinah coast was variable. The levels in Musannah, Suwaiq and Seeb have risen slightly but less in Barka. Although there has been a slight water table rise as a result of rainfall during the mentioned period, this is not above sea level, especially in Barka and Suwaiq, due to over abstraction of the aquifers and so failing to reach water balance. Figure 11 illustrates how groundwater levels fluctuate with time at two wells located near the coast along Wadi Maawil and Wadi Fara.

The presence of recharge dams along the Batinah coast has caused some rise in water levels, resulting in slightly lowered salinity, which has been observed in some of the wadis (MWR, 1995). But unfortunately the over abstraction in recent years has led to the lowering of water levels near the coast, causing salinity intrusion inland. Two main features can be distinguished: a general downward trend in water levels throughout the period of record, and a general correspondence between preceding rainfall and rises in water levels in the well. For instance, it is noticeable that the period 1990-1995 was relatively dry. This is reflected in the downward trend of water levels 

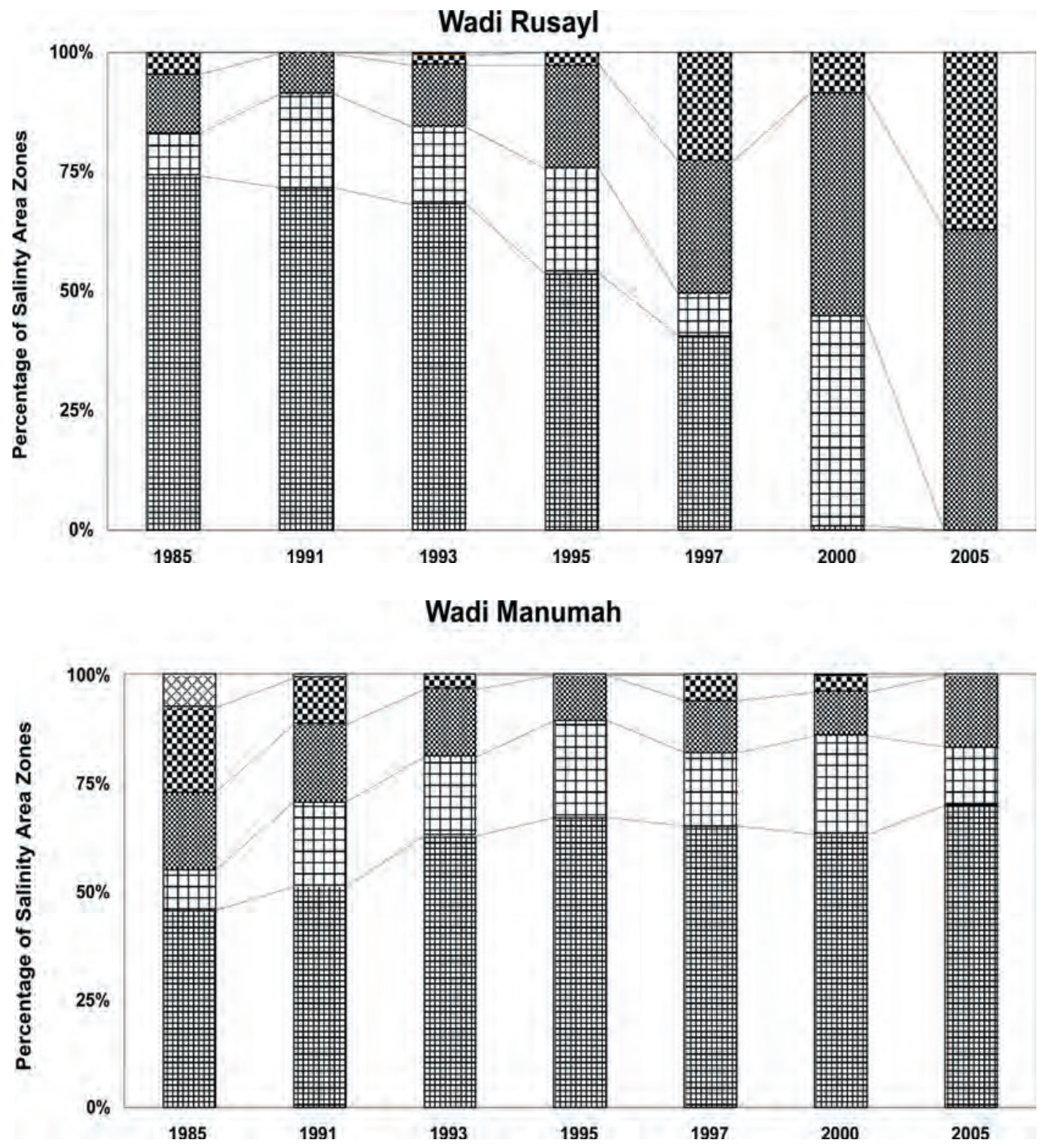

Figure 5. Salinity changes at Wadis Rusayl and Manumah areas, 1983-2005 
Wadi Samail
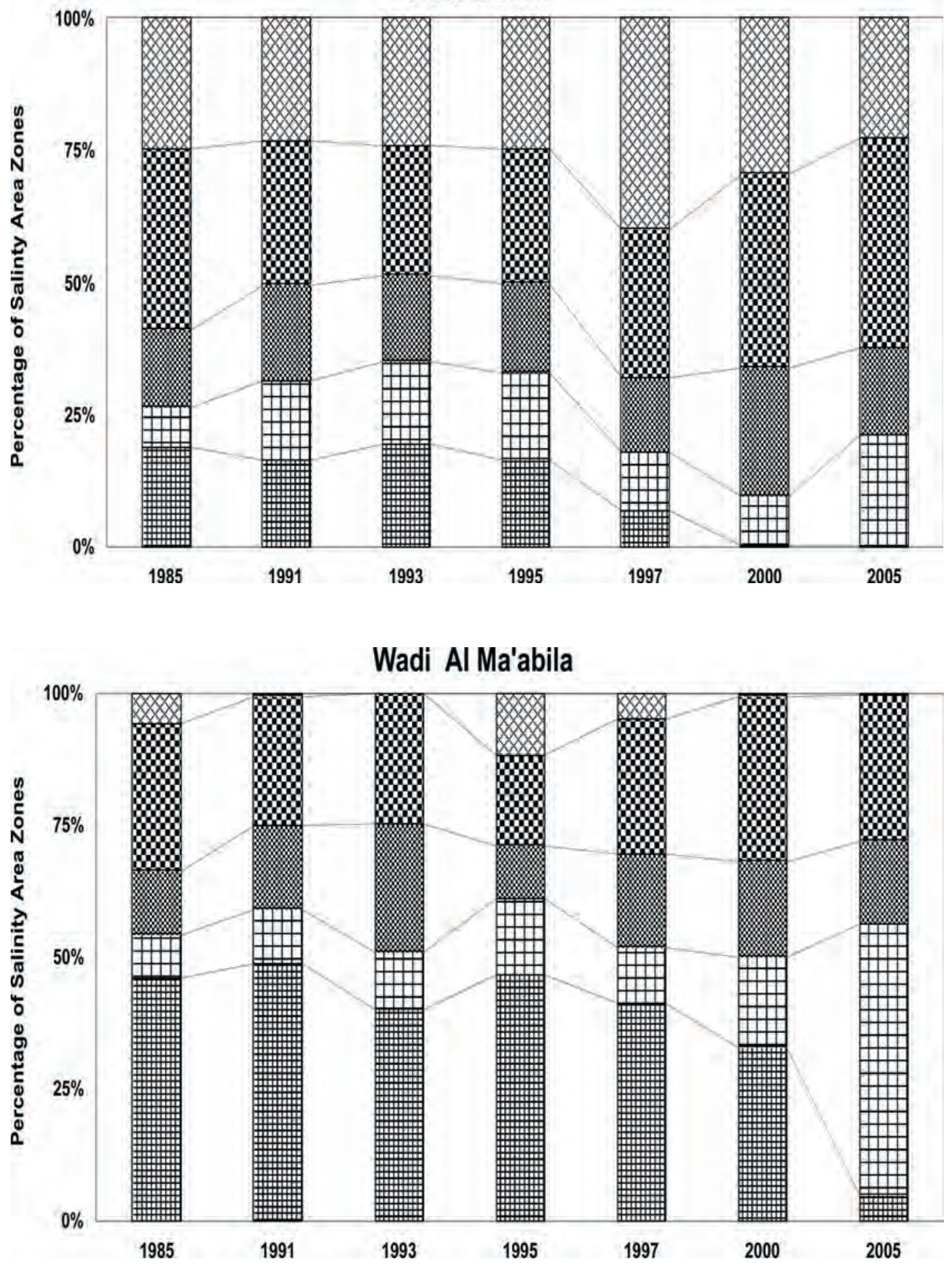

Figure 6. Salinity changes at Seeb area, 1983-2005 

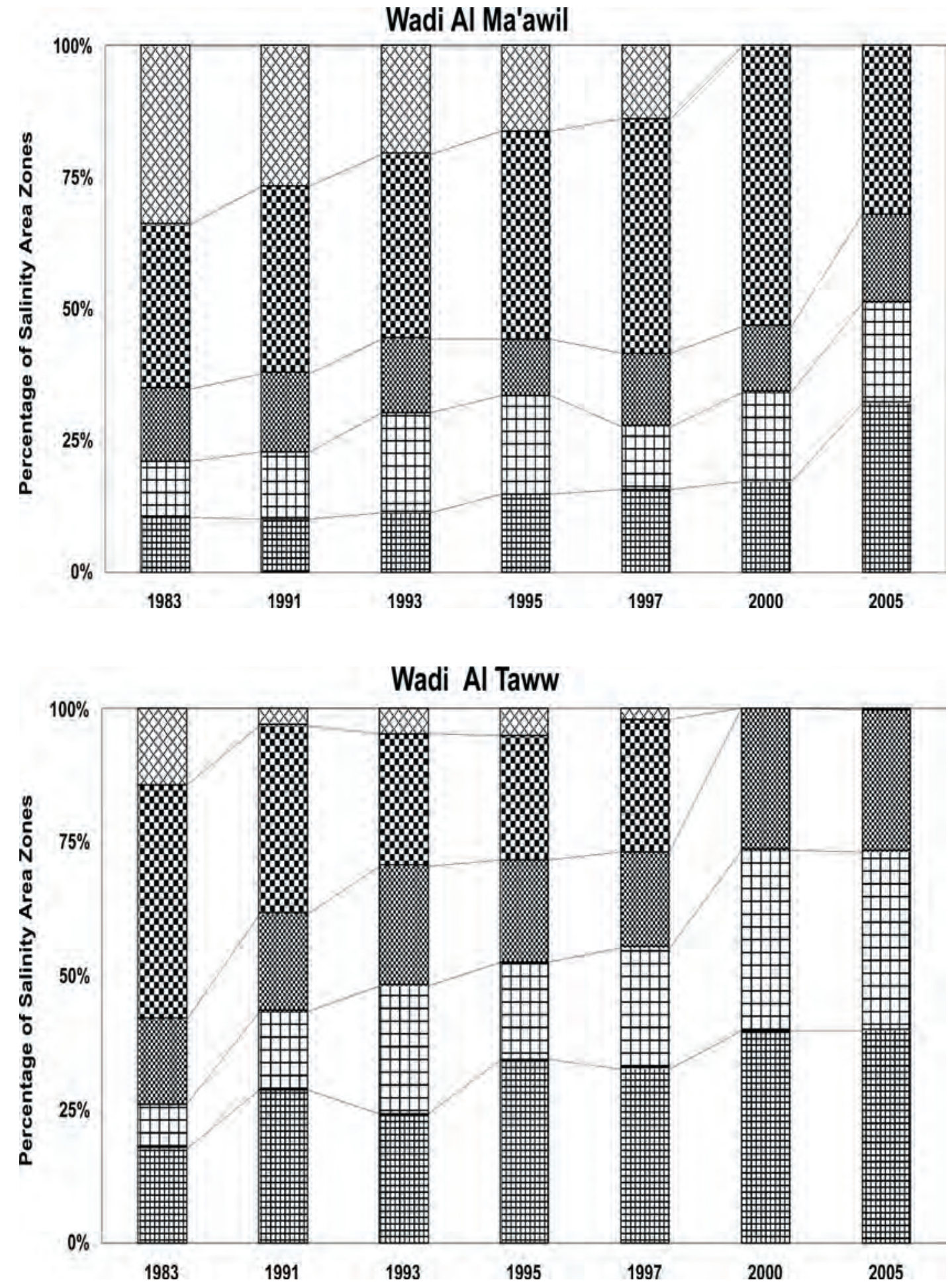

Figure 7. Salinity changes at Barka area, 1983-2005 


\section{Wadi Bani Kharous}

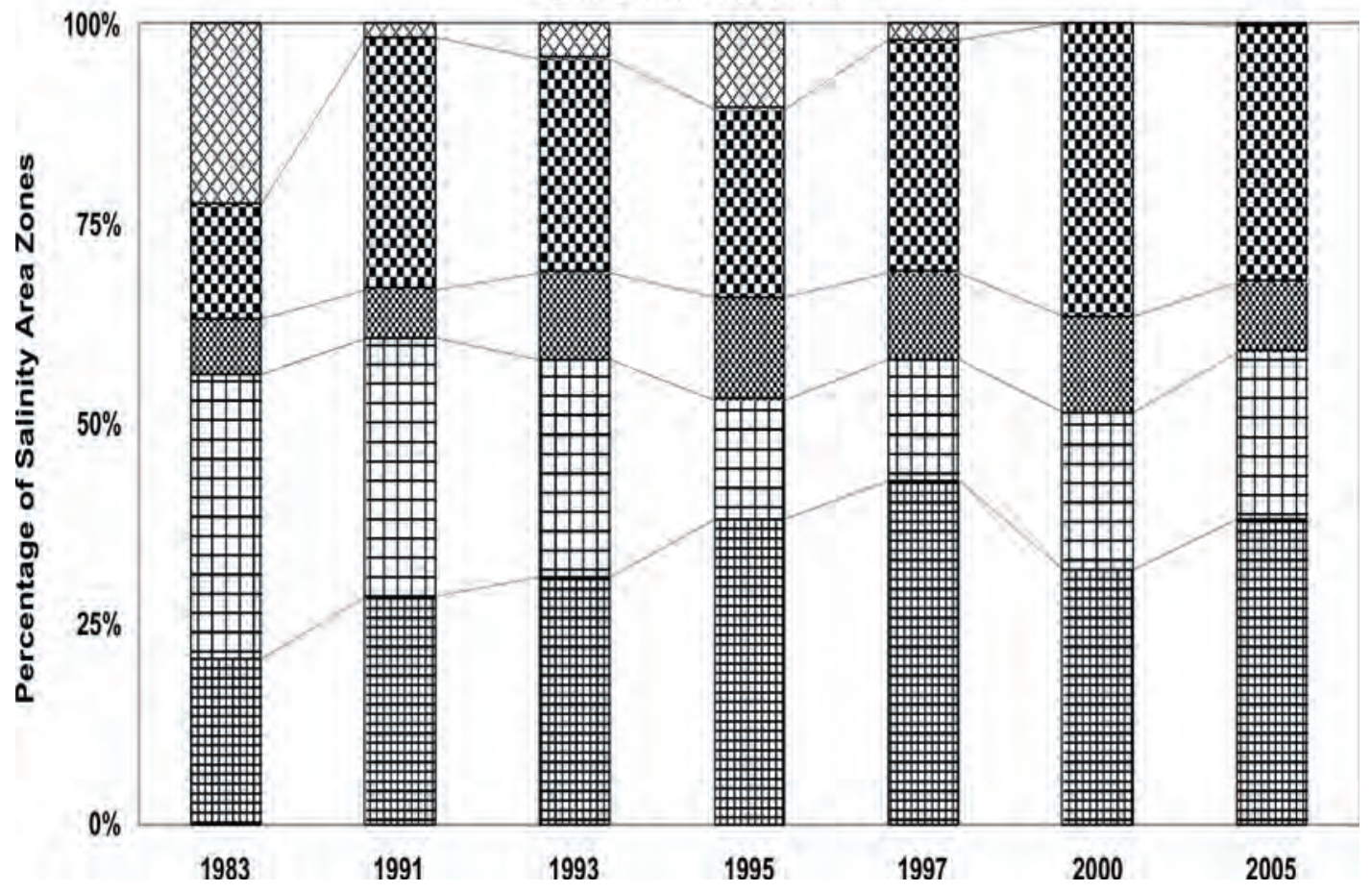

Wadi Al Fara'

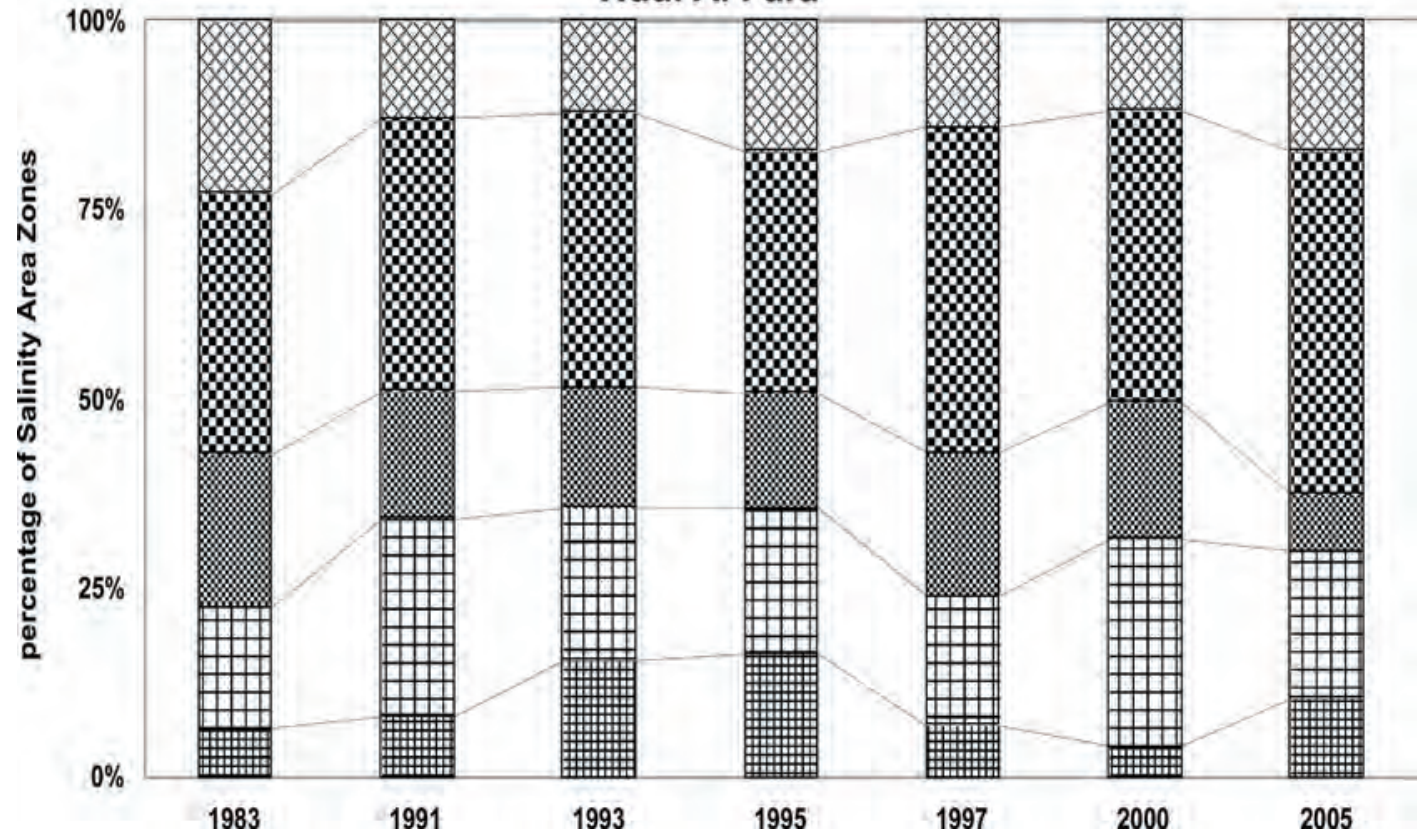

Figure 8. Salinity changes at Suwaiq area, 1983-2005 


\section{Al Khadrah Rainfall Station \\ South Batinah}

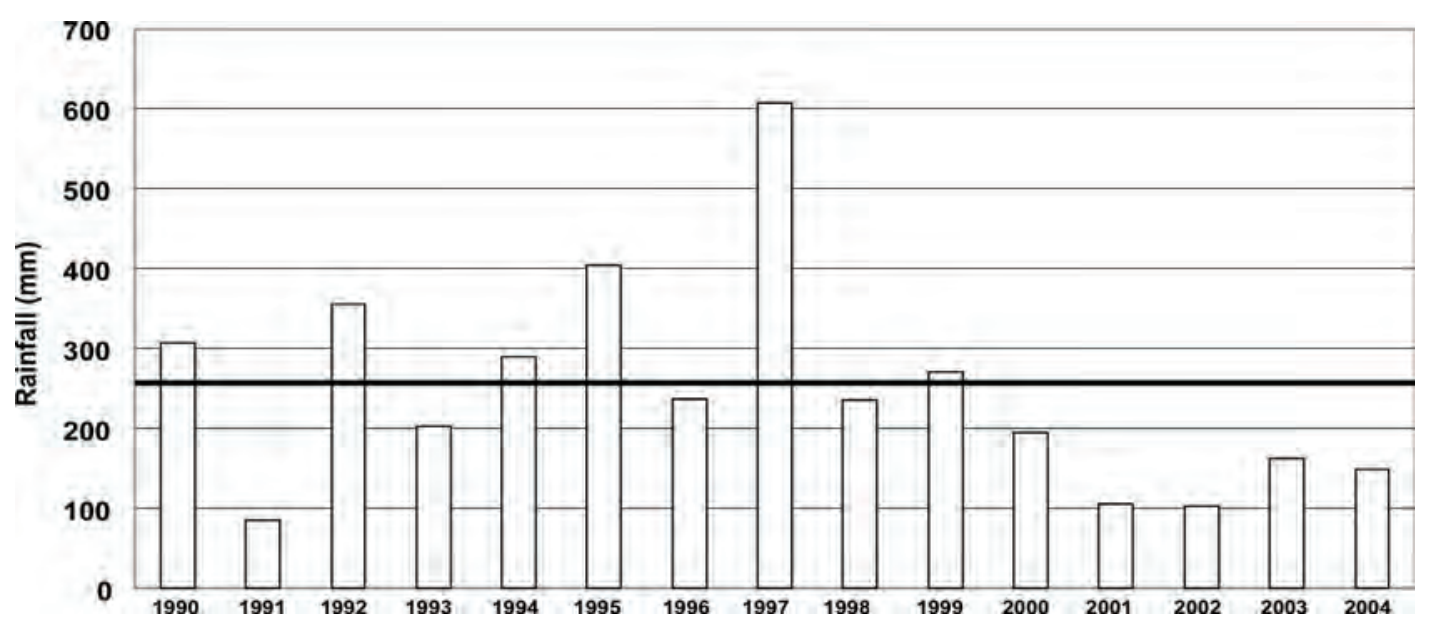

Figure 9. Yearly and average rainfall for Al Khadrah rainfall station.

during the same period. In contrast, water levels rose considerably, in 1995-1997, as result of significant rainfall at this time. Generally, in most of the selected wells the rises due to the 1997-1999 rains were much less than those following other wet periods.

\section{Effects of rainfall on salinity}

In terms of groundwater salinity, the impact of rain differs from place to place. There has been notable water quality deterioration in many catchments, such as Wadi Al Maabila, Manumah, Taw, Maawil, Bani Kharous, and Al Fara. Despite the heavy rainfall in 1997, as shown in al Khadrah station at Wadi Bani Kharous with an average annual rainfall $254 \mathrm{~mm}$, the amount was not enough to prevent groundwater deterioration in these areas. This is related to below average rainfall during $1999-2004$ and to the over abstraction, particularly in the Rumais-Barka area.

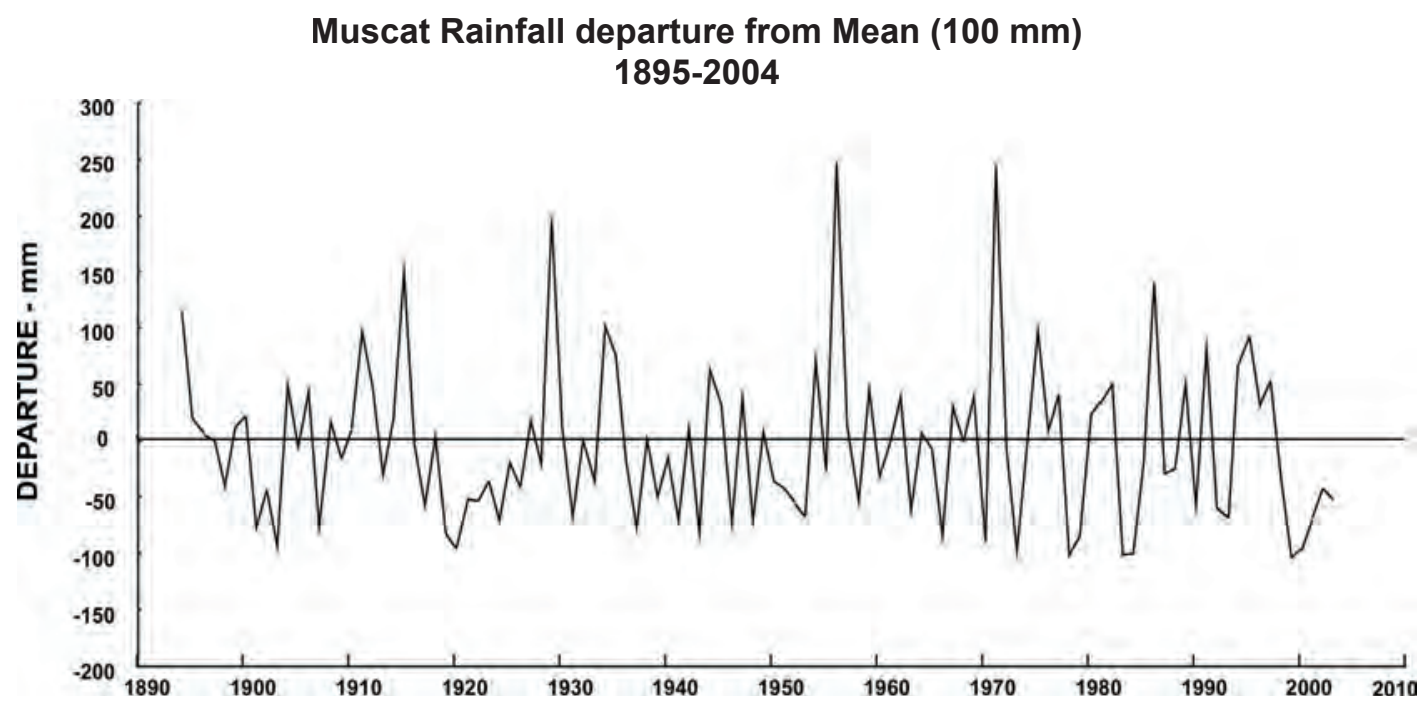

Figure 10. Muscat rainfall, departure from mean. 


\section{Monitoring Wells at South Batinah Area \\ Wadi Al Fara'}

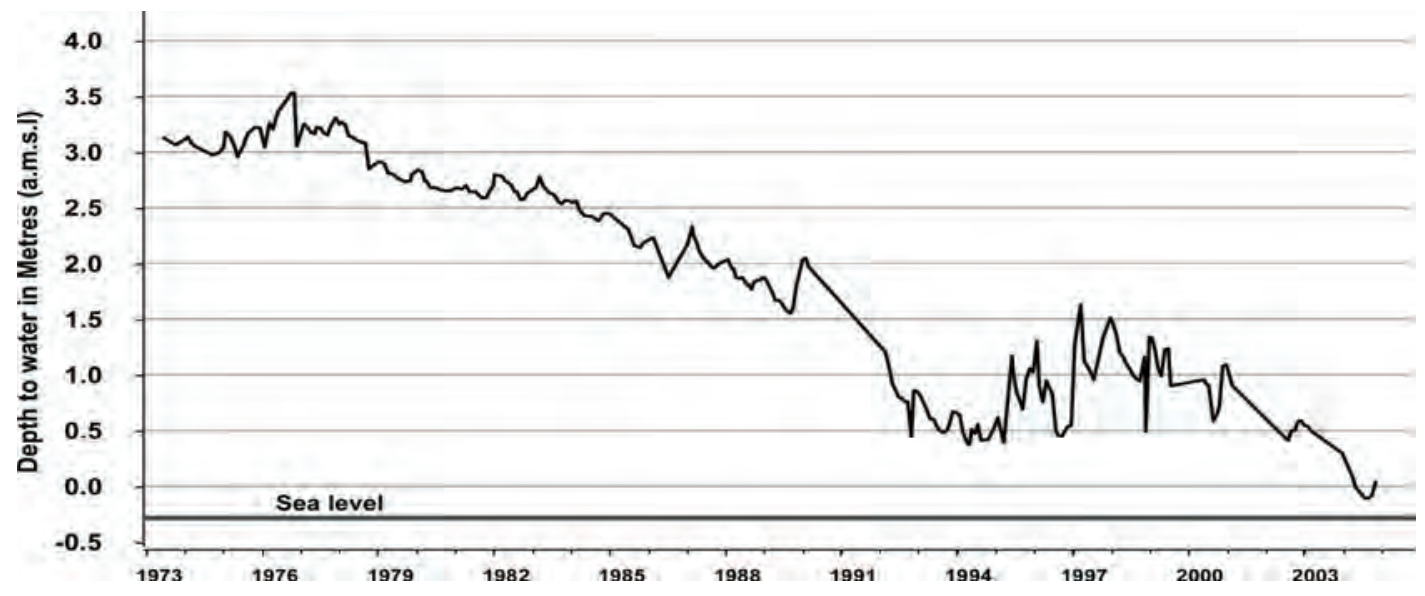

Monitoring Wells at South Batinah Area

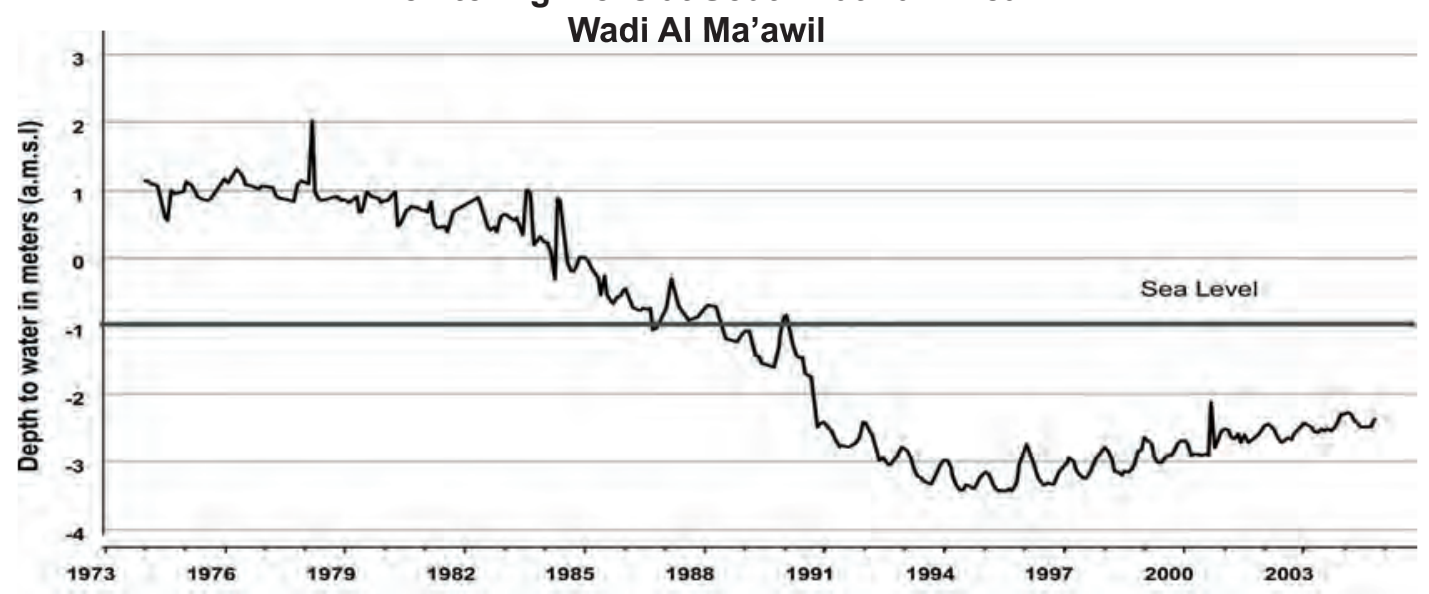

Figure 11. Groundwater levels in Wadis Al-Fara' and Maawil, 1973-2003

\section{Conclusion}

Despite exceptional natural recharge and years of water conservation, recharge enhancement and aquifer protection programmes, groundwater salinity continues to deteriorate over large areas of the Batinah. Rising salinity is probably the most economically devastating water resources problem facing the country at present. The groundwater reservoirs are still adjusting to the enormous increase in water consumption that occurred during the 1970s, 1980s and the early 1990s. Indeed, the situation may get worse, despite the improvements that occurred during the mid 1990s. Nevertheless, the situation can be addressed if all necessary actions are taken and all users behave responsibly towards this precious national resource. There is, and has been for a decade, strong evidence that tougher water resource conservation policies are required to reduce abstraction and preserve the quality of groundwater in areas where $\mathrm{EC}$ is consistently on the increase.

\section{Recommendations}

Based on these monitoring results, it is recommended to apply the following management solutions for coastal aquifer saline contamination:

- Reduce abstraction in areas of EC increase by water licensing, water tariffs, stricter control on abstraction 
by non-bona fide farmers, increased water conservation practices, improved irrigation practices, reduction of factors contributing to soil salinization, and limiting crop types according to consumption/yield.

- Enhance programs of awareness of conservation practices and farming of economic crops amongst farmers.

- Ensure all abstraction wells in problem areas are legally registered via the National Well Inventory Project records and ground checks. Abstraction at non-registered wells should be halted.

- Continue to investigate the feasibility of recharge dams, where economically viable, to prevent loss of flood water to the sea.

- Continue to develop regional management plans.
- Encourage the creation of local water user associations to engage in self-regulation.

- Change cropping patterns to low water consumption crops, stop abstraction at the amenity farms, and eliminate non economical plants.

\section{References}

MWR (Ministry of Water Resources). 1995. Ministry of Water Resources, Eastern Batinah Resources Assessment. Internal Report, September 1995, Sultanate of Oman. pp. 78.

MWR. 2000. National Water Resources Master Plan. Internal Report, October 2000, Sultanate of Oman. pp. 120.

Stanger, G. 1984. The Hydrogeology of the Oman Mountains. PhD. thesis, Department of Earth Science, The Open University, London. 